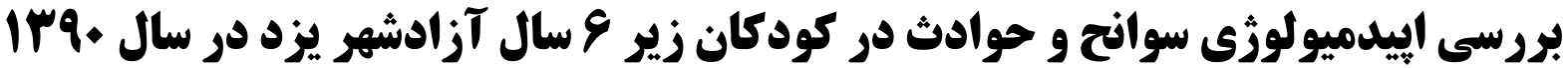

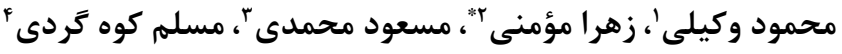

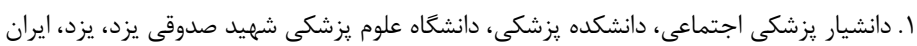

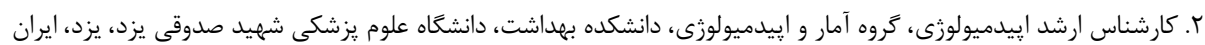

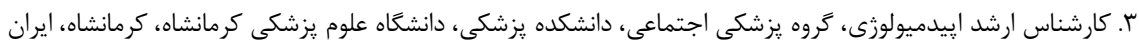

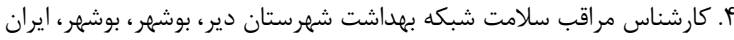

\section{Oltest}

مقدمه: سوانح و حوادث يكى از معضلات بهداشت عمومى و مهمترين علل مرك و مير كودكان در جهان

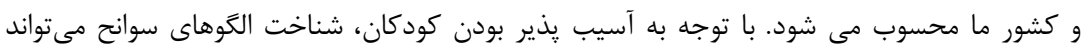
راهبردهاى مناسبى جهت يِيشيرى از سوانح فراهم نمايد. اين مطالعه با هدف بررسى إِيدميولوزى سوانح

$$
\text { و حوادث در كودكان زير } 9 \text { سال آزاد شهر يزد انجام كرفت. }
$$

روش كار: اين يك مطالعه توصيفى_تحليلى از نوع مقطعى بود. اطلاعات مربوط به ...r كودك زير \& سال با روش نمونه كيرى آسان سهميه اى از مادران مراجعه كننده به مركز بهداشتى درمانى آزاد شهر در باييز

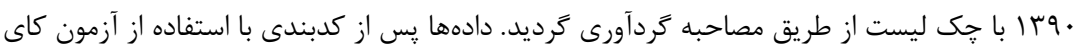

$$
\text { دو و با نرم افزار آمارى SPSS نسخه إب تجزيه و تحليل شد. }
$$

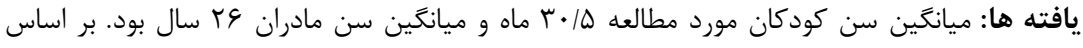

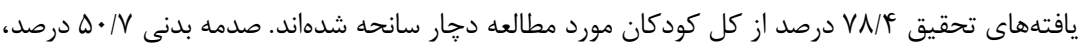

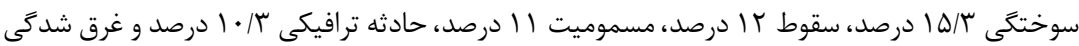
/ • درصد علل سوانح در كودكان بود. فرزندان پدران كارمند و مادران و ڤِدران با تحصيلات بالاتر، دجار

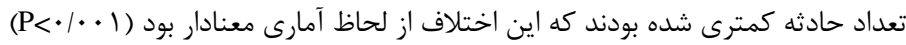
نتيجه كَيرى: آمار سوانح در آزاد شهر در مقايسه با مطالعات مشابه انجام شده رقم بالايى است لذا توصيه مى شود كه با بهره كيرى از اقدامات بِيشگيرانه ماند آموزش والدين گَامى موثر در جهت كاهش حوادث

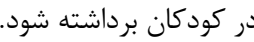

\section{مشخحات مقاله}

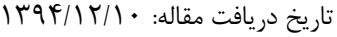

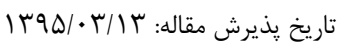

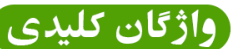

سوانح و حوادث

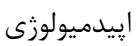

كودكان

يزد

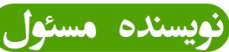

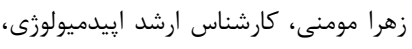

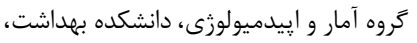

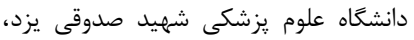

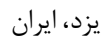

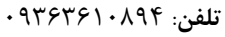

ايميل:Zmomeni547@Gmail.com

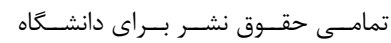

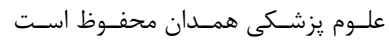

درصد از بار بيمارى ها و بالاترين ميزان مرى و مير از حوادث

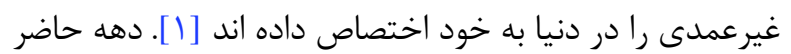

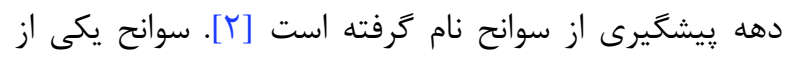

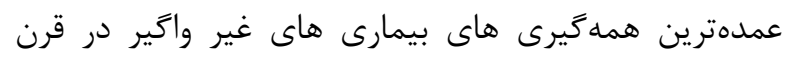

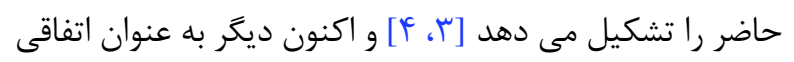

سوانح و مصدوميت ها از علل اصلى و قابل اجتناب بيماريها

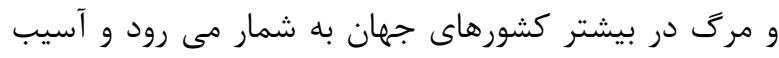

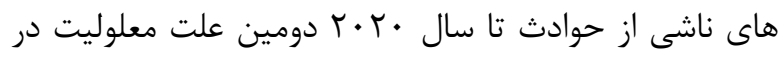

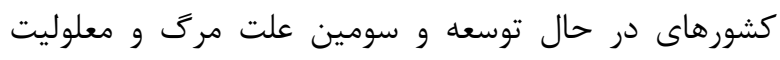

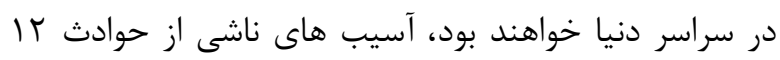


بوده [• [] كه يكى از آسيب يذيرترين گروه در خصوص آسيب ها و سوانح محسوب مى شوند [؟، 91 [1] زيرا به علت محدوديت هاى فيزيولوزيكى، فرايند رشد و نمو، يِيشرفت حسى و حركتى، ويزگى هاى رفتارى، ظرفيت واكنشى (تجربه، نياز به آموزش،

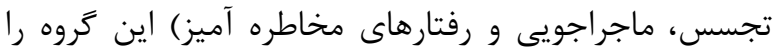
مستعد حوادث مى كند كه اين امر در كنار ساير فاكتورهاى محيطى مثل درجه ايمنى محيط، نظارت و مراقبت از سوى

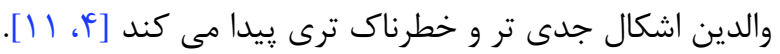

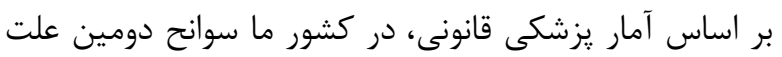
مرك و مير كودكان شناخته شده است. سوانح در كودكان به اله اشكال مختلف مشاهده مى گردد از جمله مسموميت ها، سقوط از بلندى، برق كرفتكى، خفكى، سوختكى، صدمات ناشى از

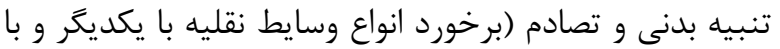
عابر پياده، يرتاب سنَ يا وسايل ديخر و غيره)، كه با توجه به به سن كودى نوع خاصى از سانحه در آنها بيشتر اتفاق مى افتد

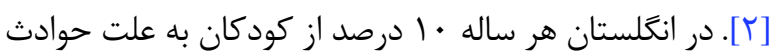

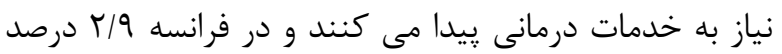

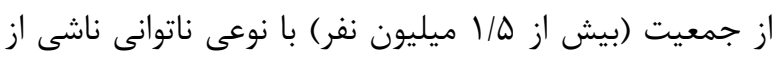
حوادث زندكى مى كنند [1 11] و در تحقيقى كه در تهران انجام شد از سوانح به عنوان شايعترين علت مرك و مير در سنين

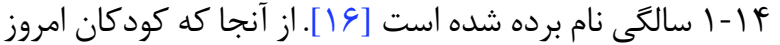
آينده سازان فرداى جامعه هستند، شناخت الكوهاى سوانح و حوادث در اين كروه سنى جهت برنامه ريزى اصولى در جهت

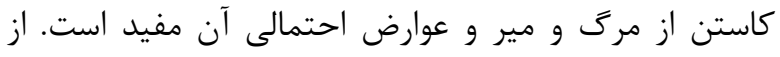
اين رو برآن شديم كه به بررسى وضعيت سوانح و حوادث در كودكان زير 9 سال در مركز آزادشهر يزد بيردازيم.

روش كار اين تحقيق يك مطالعه توصيفى_تحليلى مىباشد كه به روش مقطعى انجام گرفته است. جمعيت مورد بررسى، مادران داراى كودك زير 4 سال مراجعه كننده به كلينيك مركز بهداشتى

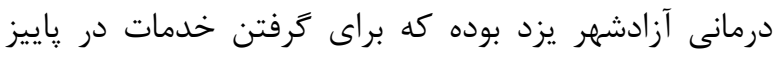

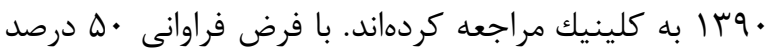

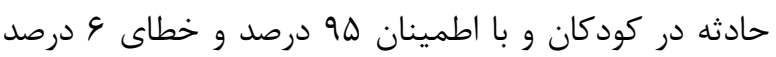

و تصادفى محسوب نمى شود، بلكه بخشى از بهايى است كه

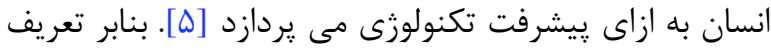

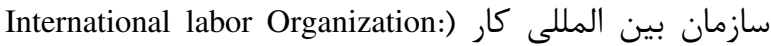
(ILO حادثه يك اتفاق ييش بينى نشده و خارج از انتظار است آنان

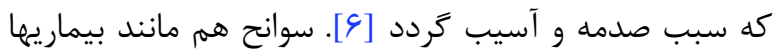

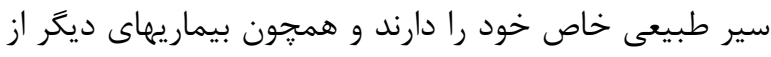

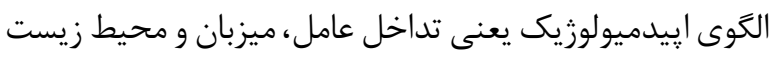

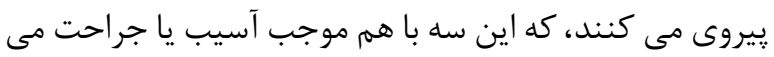

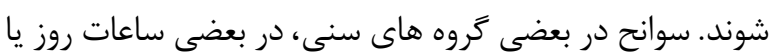
هفته و در بعضى جاهاى معين خيلى بيشتر بروز مى كنند [V] بر اساس آمارهاى منتشر شده ضايعات ناشى از حوادث يكى از ينج علت عمده مرگ در گروه هاى مختلف سنى در كشورهاى ييشرفته و در حال پيشرفت است [^] و يكى از مهم ترين عوامل ايجاد كننده معلوليت ها در كشورهاى توسعه يافته دنيا مى باشد [9، 1] و همجنين هزينه ها و مخارج ناشى از حوادث

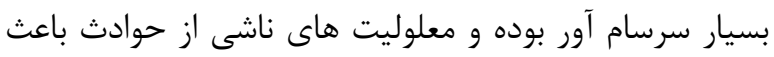
از دست رفتن نيروى انسانى فعال به همراه ميليونها ساعت كار مفيد مى كردد [1 11]. بر اساس آمار مركى و مير كودكان زير 4

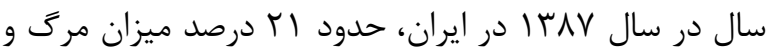
مير مربوط به حوادث و سوانح غيرعمدى است كه از اين ميزان بF درصد به حوادث خانكى و FT/A د درصد به حوادث ترافيكى اختصاص دارد [TI]]. كشور ايران در زمينه بروز حوادث و تصادفات در گروه نخستين كشور هاى جهان قرار دارد [1 ا []، در كشورهاى غربى بعد از مرى و مير به علت بيمارى هاى قلبى و سرطان ها، حوادث در درجه سوم شيوع قرار كرفته است

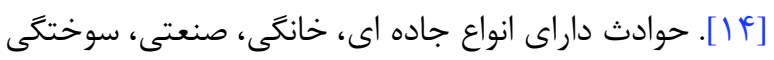

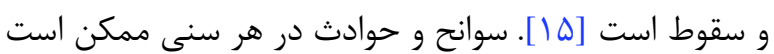

اتفاق بيفتد [9]. آسيب، خطر عمدهى سلامت بالغين در دنيا و شايعترين علت مرك در سنين TF-I سال محسوب مى شود و مرك و مير ناشى از آسيب در كروه هاى سنى كودكان و نوجوانان بيشتر از بيمارى هاى قلبى عروقى و سرطان است

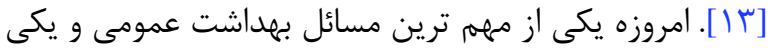
از علل اصلى مرگ و مير در جوامع مختلف اعم از جوامع صنعتى و ييشرفته و يا در حال توسعه مسئله سوانح در كودكان 
مجموع سقوط در دختران بيشتر از يسران بوده است در حاليكه بقيه سوانح در يسران بيشتر بوده است. توزيع فراوانى ويزگگى هاى فردى و خانوادگى نمونه هاى يزوهش بر حسب رخداد و عدم رخداد سانحه در קاييز •وسا در جدول شماره r نشان داده شده است. بر طبق نتايج ع/ع درصد از فرزندان جهارم و بالاتر اصلاً حادثه نديده بودند در حاليكه \| • ه درصد از فرزندان اول حادثه نديده بودند. كودكان اول خانواده بيشتر دجار حادثه شده بودند. در اين جدول مشاهده مى شود كه هرجه رتبه تولد افزوده شده فرزندان با تعداد حادثه كمترى مواجه شدهاند هرجه رتبه تولد افزايش يافت درصد كودكان دجار حادثه و تعداد سوانح كم شد ولى از نظر آمارى رابطه معنى دارى بين تعداد كل سانحه و رتبه تولد فرزندان بدست نيامد (1/ (P=). طبق اين جدول • F درصد از فرزندان קدران كارمند دجار حادثه

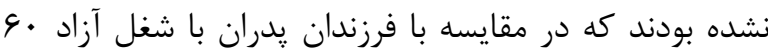
درصد آمار قابل توجهى است. همجنين فرزندان يدران كارمند

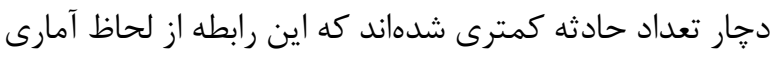

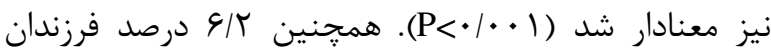
مادران كارمند اصلاً دجار حادثه نشده بودند كه در مقايسه با فرزندان مادران خانهدار /1/ه درصد آمار خيلى كمترى است (P=•/19). هرجه سطح تحصيلات گیدر بالاتر رفته تعداد سوانح كمتر شده است. همجنين رابطه آمارى معنادارى بين تعداد سوانح با ميزان تحصيلات يدر وجود دارد ( ( • ( و همينطور رابطه آمارى معنادارى بين تعداد سوانح با ميزان تحصيلات مادر وجود دارد در كل هر جه ميزان تحصيلات در والدين بالاتر رفته تعداد حادثه كمتر شده است ( ( + P> P).

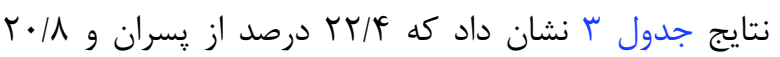
درصد از دختران اصلًً دجار حادثهاى نشده بودند اكثريت دختران (\&/\& د درصد) يك حادثه ديده بودند در حاليكه ( درصد) از يسران دو حادثه و بيشتر ديده بودند كه بر حسب آزمون كاى دو تعداد سوانح به تفكيك جنسيت از نظر آمارى

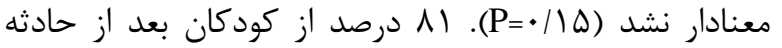
سالم بوده 91 درصد داراى نقص جزئى و r درصد بسترى در بيمارستان شده بودند كه از 9 مورد (r درصد) بسترى در

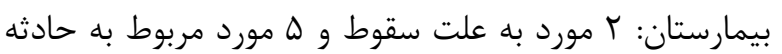

حجم نمونه لازم Y\&V نفر برآورد شد و براى اطمينان بيشتر • . . نفر وارد مطالعه شد. براى نمونه گيرى از روش آسان سهميه اى استفاده شد، ابتدا أ روز كارى از هفته هاى اول و سوم مهر و هفته هاى دوم و :ههارم آبان به تصادف انتخاب شد و با شروع مطالعه در هريك از اين جهار روز و ادامه آن در روزهاى متوالى بعدى، تمام مادران داراى كودك زير شش VD سال مراجعه كننده به مركز به طور سرشمارى تا تكميل نمونه وارد مطالعه شدند تا حجم كلى . .ب نمونه تكميل شد. قابل ذكر است كه موارد تكرارى وارد مطالعه نمى شدند. لازم به ذكر است در اين تحقيق منظور از نقص جزئى آسيبى است كه منجر به مراجعه سرويايى به مراكز ارائه خدمات سلامتى اعمم از خصوصى يا دولتى شده اما كودى بسترى نشده باشد. براى جمع آورى داده ها فرم مخصوصى به شكل جى ليست طراحى شد كه در بخش اول اطلاعات دموگرافيكى شامل جنس و سن كودك، رتبه تولد كودى، ميزان تحصيلات والدين، شغل والدين، سن مادر و در بخش دوم نوع حادثه و علت آن ، نتيجه حادثه به روش مصاحبه با مادران مراجعه كننده به كلينيك تكميل گرديد. سيس اطلاعات بدست آمده كد بندى و وارد كامييوتر شد و با آمار توصيفى شامل ميانگين و درصد فراوانى و آمار استنباطى شامل آزمون آمارى X' و با استفاده از نرم افزار آمارى SPSS نسخه اب در سطح خطاى ه درصد تجزيه و تحليل شد. - 20 - n

كافته ها

در اين مطالعه وها كودك يسر (Y ه درصد) و IFF

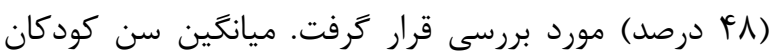

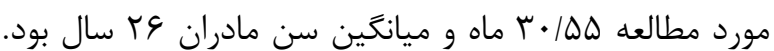
يافتههاى تحقيق نشان مىدهد كه VA/4 درصد از كل كودكان

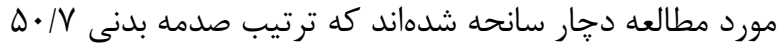
درصد، سوختخى س/ه ادرصد، سقوط | | درصد، مسموميت $1 \mid$ درصد، حادثه ترافيكى س/ • ا درصد و غرق شدگى V/ • درصد سوانح در كودكان مى باشد. در جدول شماره يك نوع حادثه به تفكيك جنسيت در كودكان زير \& سال آزادشهر نشان داده شده است. همانطور كه در جدول شماره ا مشاهده مى شود در 


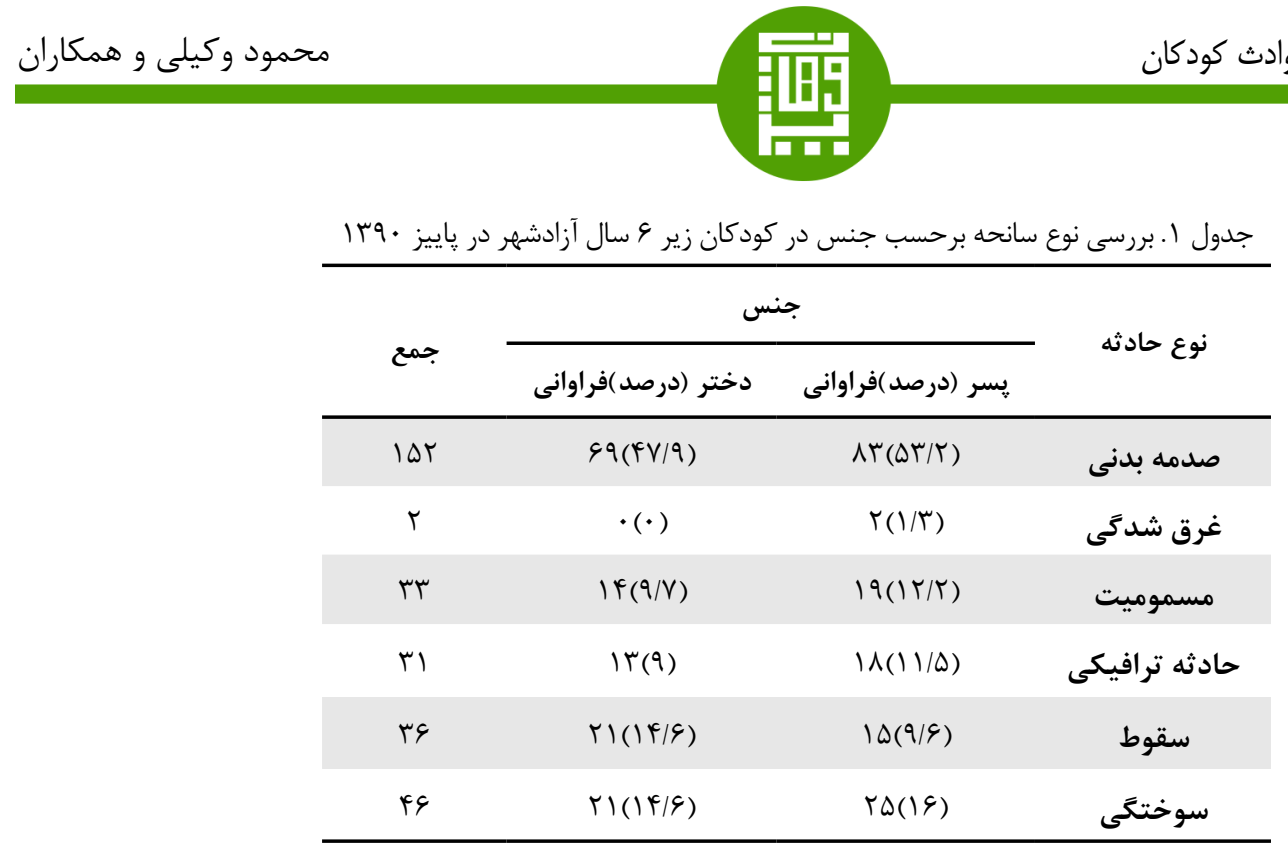

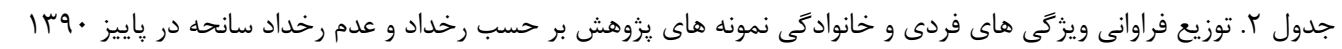

\begin{tabular}{|c|c|c|c|c|}
\hline سطح معنادارى & فراوانى موارد عدم سانحه & فراوانى موارد سانحه ديده & \multicolumn{2}{|c|}{ ويثزى } \\
\hline \multirow[b]{2}{*}{$\mathrm{P}=\cdot / F r$} & $r \Delta(\Delta r / \Lambda)$ & $|r|(\Delta \mid / \Delta)$ & يسر & \\
\hline & $r \cdot(\uparrow \in / r)$ & $\| f(f \wedge / \Delta)$ & دختر & جنس \\
\hline \multirow{4}{*}{$\mathrm{P}=\cdot / 1$} & $r r(\Delta \cdot / \Lambda)$ & $\mid f \wedge(\xi \mu)$ & اول & \multirow{4}{*}{ رتبه تولد } \\
\hline & $r \cdot(r \cdot \mid \Lambda)$ & $G \vee(Y \wedge / \Delta)$ & دوم & \\
\hline & $9(\mid r / \Lambda)$ & $19(8 / 1)$ & سوم & \\
\hline & $r(\boldsymbol{\varphi} / \varphi)$ & $F(1 / V)$ & קهارم و بالاتر & \\
\hline \multirow{2}{*}{$\mathrm{P}<\cdot / \cdots 1$} & $r q\left(r^{*}\right)$ & 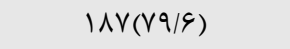 & كارمند & \multirow[b]{2}{*}{ شغل يدر } \\
\hline & ५q(9.) & $\mathcal{F} \wedge(Y \cdot / \mathcal{Y})$ & آزاد & \\
\hline \multirow{4}{*}{$\mathrm{P}<\cdot 1 \cdot \cdots 1$} & $I r(r \cdot)$ & $\operatorname{Fr}(I V / 9)$ & ابتدايى & \multirow{4}{*}{ تحصيلات يدر } \\
\hline & $11(19 / 9)$ & $99(F Y / I)$ & راهنمايى & \\
\hline & $r \cdot(F \in / T)$ & $\Lambda r(r Y / q)$ & دييلم & \\
\hline & $11(19 / 9)$ & $1 r(\Delta / 1)$ & بالاتر از دييلهم & \\
\hline \multirow{2}{*}{$\mathrm{P}=\cdot / 19$} & $f(\varphi / T)$ & $V(r)$ & كارمند & \multirow[b]{2}{*}{ شغل مادر } \\
\hline & 9) $(94 / \Lambda)$ & TY^(9V) & خانه دار & \\
\hline \multirow{4}{*}{$\mathrm{P}<\cdot / \cdot \cdot 1$} & $r \cdot(r \cdot \mid \Lambda)$ & $q \mu(५ q / \varphi)$ & ابتدايى & \multirow{4}{*}{ تحصيلات مادر } \\
\hline & $11(19 / 9)$ & $91(T \varphi)$ & راهنمايى & \\
\hline & $\Gamma \wedge(\Gamma+/ I)$ & V৭(Tr/G) & دييلم & \\
\hline & $9(9 / 7)$ & $r(\cdot / 9)$ & بالاتر از دييلهم & \\
\hline
\end{tabular}

جدول r. بررسى تعداد سوانح به تفكيك جنس در كودكان زير 9 سال آزادشهر در ياييز •وبا

\begin{tabular}{|c|c|c|c|}
\hline \multirow{3}{*}{ سطح معنادارى } & \multicolumn{2}{|c|}{ 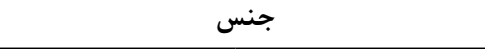 } & \multirow{2}{*}{ تعداد حادثه } \\
\hline & دختر (درصد)فراوانى & يسر (درصد)فراوانى & \\
\hline & $r \cdot(r \cdot / \Lambda)$ & $r \Delta(Y T / F)$ & اصلاً حادثهاى رخ نداده باشد \\
\hline \multirow[t]{2}{*}{$\mathrm{P}=\cdot / 1 \mathrm{Q}$} & $q \mu(g Y / \varphi)$ & $\Lambda \notin(\Delta \Delta / 1)$ & يك حادثه رخ داده باشد \\
\hline & $r \mid(\mid Y / 9)$ & $r \Delta(Y T / F)$ & دو حادثه و بيشتر رخ داده باشد \\
\hline
\end{tabular}


ترافيكى و ا مورد به علت سوختگى و ا مورد به علت صدمه مشاهده مى شود بين وضع بدنى كودك يٍ از حادثه به تفكيك

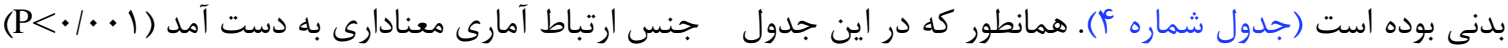

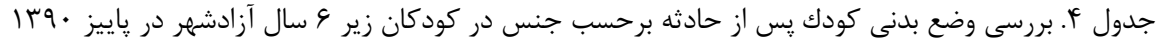

وضع بدنى كودك

\begin{tabular}{|c|c|c|c|c|}
\hline \multirow[t]{2}{*}{ سطح معنادارى } & بسترى در بيمار ستان (درصد )تعداد & نقص جزئى(درصد) تعداد & سالم (درصد) تعداد & \\
\hline & $\cdot(\cdot)$ & r\&(IS/V) & $\mathbb{I r \cdot ( \Lambda r / r ) ~}$ & 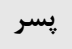 \\
\hline \multirow[t]{2}{*}{$\mathrm{P}<\cdot / \cdot \cdot 1$} & $q(\varphi / T)$ & $T r(\mid \Delta / T)$ & $\| r(\vee \wedge / \Delta)$ & 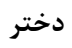 \\
\hline & $9(r)$ & $\forall \wedge(19)$ & FFY(AI) & جمع \\
\hline
\end{tabular}

آمارى معنادارى نشان داد. در مطالعه ما دو حادثه و بيشتر براى

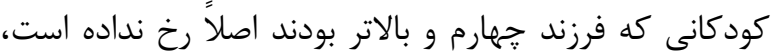
مىتوان اين طور توجيه كرد كه مادر به علت داشتن فرزندان قبلى، تجربه و اطلاعات بيشترى دارد. همجنين در مطالعه حاضر رابطه معنى دارى بين شغل يدر با كل سانحه وجود داشت. به طورى كه فرزندان يدرانى كه شغل آزاد داشتند كمتر

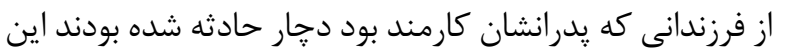

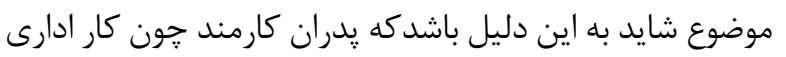

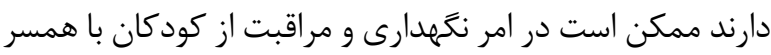

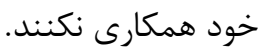
فرزندان مادران كارمند كمتر از فرزندان مادران خانهدار دجار حادثه شده بودند همجنين فرزندان مادران كارمند فقط يك حادثه داشتهاند درحاليكه فرزندان مادران خانهدار دو حادثه و هاندان بيشتر هم داشتهاند. مادران كارمند به علت اينكه وقت كمترى در منزل با فرزندان خود دارند از همان اول آموزشهاى لازم با بان إنا

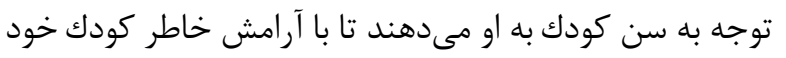

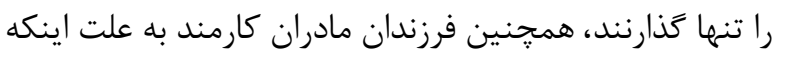
از همان سالهاى اول زندگى، در مهدكودك قرار مى گيرند اعتماد

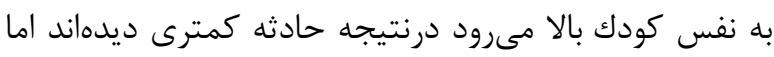
در مطالعه اسماعيلى و همكاران [T] شغل NN/A درصد مادران كودكان حادثه ديده خانه دار گزارش كرديده است. بنابراين نقش آموزش هاى مناسب براى مادران خانه دار جهت يِيشَيرى از سوانح و حوادث در كودكان بسيار مهم است. در اين مطالعه
مطالعه اى مقطعى به منظور بررسى إيدميولوزى سوانح و حوادث در كودكان زير 9 سال آزادشهر يزد انجام شد. يافتههاى حاصل از اين مطالعه نشان داد كه VN/F درصد از كل كودكان مورد مطالعه دجار سانحه شده بودند كه ترتيب

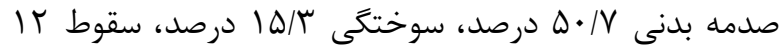
درصد، مسموميت || درصد، حادثه ترافيكى س//• آدرصد و

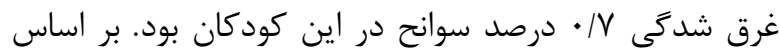
اين مطالعه آمار سانحه در مركز آزادشهر نسبت به تحقيقات

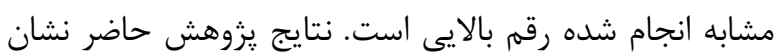
داد توزيع جنسى واحدهاى يزوهش شامل VV/D درصد مذكر و V9/T درصد مؤنث بود كه دجار سانحه شده بودند اما در مطالعه Sridharan حوادث در كودكان داراى جنسيت مذكر بيشتر بود. در اين يروهش تعداد سوانح دو تا و بيشتر در دختران V/A درصد كمتر از يسران بوده است كه اين مى تواند به علت الكوهاى رفتارى ويزه و حس كنجكاوى بيشتر يسران نسبت به دختران باشد.

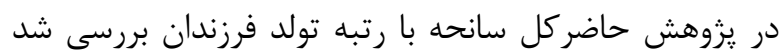
در اين باره اختلاف معنادارى مشاهده نشد به طورى كه د1/1 درصد فرزندان اول خانوادهها دجار حادثه شده بودند و هرجه رتبه تولد افزايش يافت تعداد سانحه كمتر شد اما در مطالعه اسماعيلى و همكاران [r] اكثر كودكان حادثه ديده سومين فرزند خانواده بودند و در مطالعه مظلومى و همكارش [11] در يزد افزايش وقوع حادثه با تعداد فرزندان در خانواده رابطه 
ناتوان از حركت و تحت نظارت نزديك اطرافيان مى باشند. در مطالعه نكويى مقدم و همكاران [9 19] و ايزدى [11] بيشترين حوادثى كه براى كودكان ييش آمده بود صدمه بدنى (آسيب ناشى از ضربه) بود كه اين همسو با يافته مطالعه حاضر است. در مطالعه بيات و همكاران [IV] بيشترين علت صدمه در كود كان به ترتيب سقوط از ارتفاع (ه/V ب/V درصد)، مسموميت درصد)، تصادف (1/V/ درصد)، سوختخى( ( / درصد) بود.

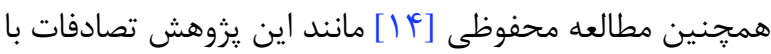
ه D/AV حواث را در كودكان داشته است همجنين در مطالعه اسماعيلى و همكاران در مازندران [ץ] سقوط اولين علت عمده سوانح در كودكان و تصادم دومين علت ذكر شده است و در مطالعه بخشى در رفسنجان [ب] تصادف رتبه اول حوادث و بعد از آن سقوط و زمين خوردن ذكر شده است و در مطالعه Ganveer و همكاران [10] سقوط با اY درصد بيشترين ميزان و غرق

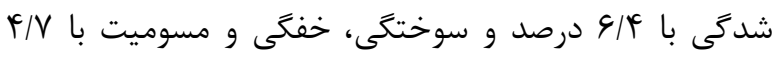
درصد در مراحل بعدى قرار دارند در مطالعه مهرام و همكاران سانحه به دليل زمين خوردن در رتبه اول قرار داشت. جون آيتممهاى مورد بررسى با تحقيقاتى كه همكاران انجام دادهاند و مكانى كه براى انجام مطالعه انتخاب شده با بقيه فرق داشت آمار و ارقام كمى متفاوت مىباشد نقطه ضعف مهرم اين يروهش عدم توجه به كودى آزارى بود كه به احتمال زياد يك عامل شايع ولى ينهان آسيب هاى فيزيكى در كودكان زير 4 سال مى باشد.

نتيجه كيرى با توجه به مشخص شدن الخوهاى سوانح در كودكان زير 4 سال ييشنهاد مى شود با بهرهگيرى از اقدامات ييشخيرانه درخصوص سوانح براساس ويزگى هاى آن در هر منطقه بايدكامى موثر در جهت كاهش سوانح برداشت. شناسايى عوامل خطر و تعيين كنندههاى محيطى، روانى، رفتارى و اجتماعى و ساير عوامل مىتوانند كاهش آسيب ها را تسهيل و تسريع نمايد و همجنين كشف عوامل خطر و اثر متقابل آنها بر يكديگر و روابط آنها با آسيب ها مىتواند در ايجاد فرضيههاى جديد
بين تحصيلات يدر با كل سانحه رابطه آمارى معنادار به دست آمد، هرجه سطح تحصيلات يدر افزايش يافت كودكان كمتر دجار حادثه شدند. همجنين بين تحصيلات مادر با كل سانحه رابطه آمارى معنادار به دست آمد مسلم است كه هر خه ميزان آكاهى خانوادهها افزايش يابد دقت بيشترى در زندگى دارند. در مطالعه اسماعيلى و همكاران [ץ] سطح تحصيلات ץ/ سא درصد مادران كودكان حادثه ديده در مقطع ابتدايى بود، در مطالعه مظلومى و همكارش [11] در يزد بين تعداد فرزند در خانه و سواد مادر با وقوع حوادث نيز ارتباط آمارى معنادار مشاهده شد. در مطالعه حاضر بين وضع بدنى كودك يس از حادثه به تفكيك جنس ارتباط آمارى معنى دارى به دست آمد و يسران بعد از حادثه سالم تر و نقص جزئى كمترى نسبت به دختران داشتند و 9 مورد بسترى در بيمارستان دختران بودهاند، جون دختران جز گروه آسيب يذير هستند بيشتر صدمه ديدهاند و بين شغل والدين با وضع بدنى كودك پِ از حادثه رابطه آمارى معنى دارى به دست نيامد. همجنين بين تحصيلات مادر با وضع بدنى كودك يس از حادثه نيز رابطه معنادار به دست نيامد درحاليكه بين تحصيلات پدر با وضع بدنى كودك يس از حادثه رابطه آمارى معنادار بدست آمد. سقوط در دختران بيش از يسران بوده درحاليكه بقيه سوانح در گِران بيشتر بود، اين امر مى تواند به اين دليل باشد كه معمولا جسارت يسرها براى خطريذيرى بيشتر است [9 19]. يافتههاى تحقيق نشان مى دهد كه صدمه بدنى با V/ • ه درصد بيشترين علت حادثه بوده است.

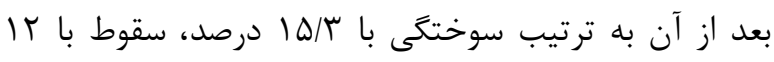
درصد، مسموميت با || درصد، حوادث ترافيكى با س/ • إدرصد

و غرق شدگى با V/ • درصد علل سوانح به دست آمد. در مطالعه ساسان و همكاران [• [ب] يافته ها نشان داد، بيشترين سانحه در

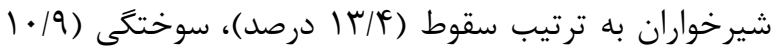
درصد)، مسموميت (T/9 درصد)، تصادف با وسايل نقليه (ه/ه درصد)، غرق شدگى (V/• درصد) بود كه تضاد اين با يافته مطالعه حاضر مى تواند به دليل زروه هاى مورد بررسى در دو مطالعه باشد زيرا در مطالعه ساسان و همكاران شيرخواران F G - F ماهه بررسى شده بودند و انتظار نمى رود كودكان در اين سنين در معرض خطر سوانح تصادفى باشند جرا كه آنها نسبتا 


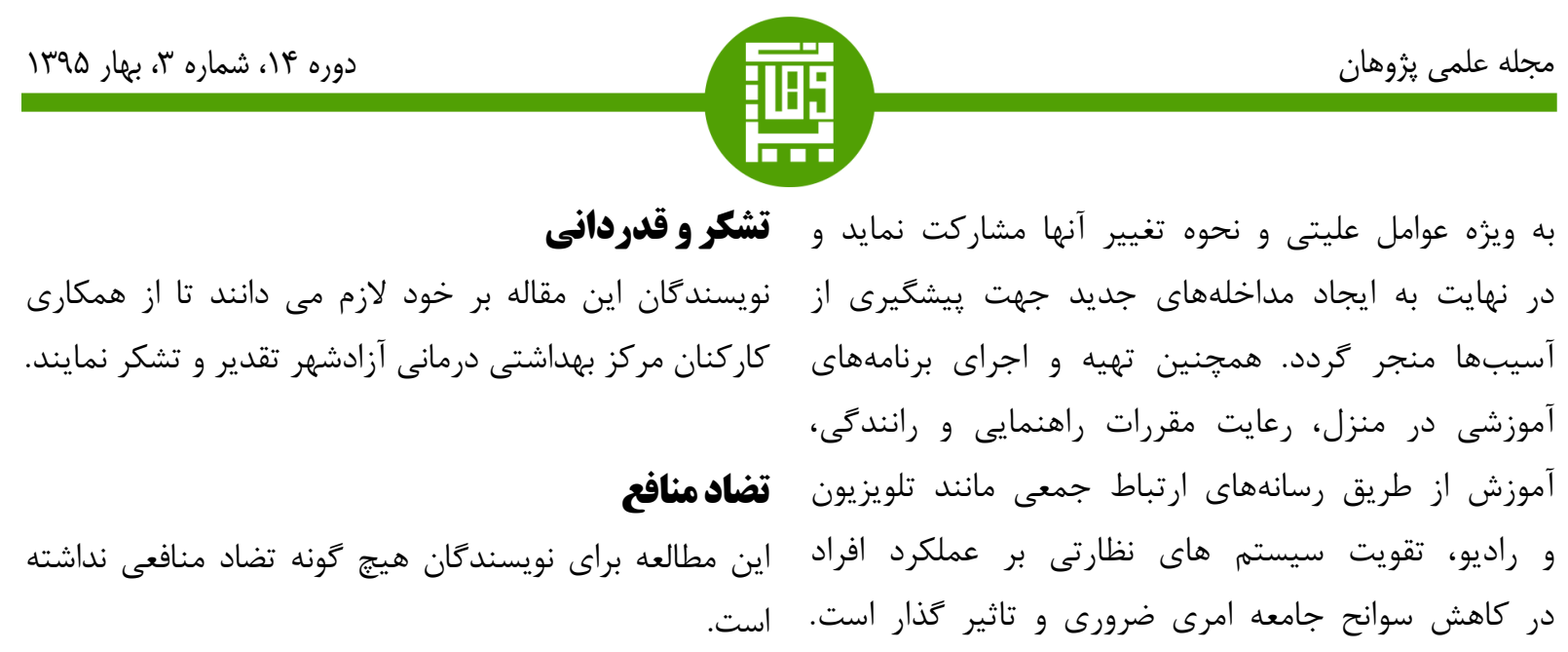

\section{References}

1. Khazaei S, Mazharmanesh S, Khazaei Z, Goodarzi E,

Yektaparast M. Investigation of accidents in the home Mirmoini R, Mohammadian-Hafshejani A and et al. An epidemiological study on the incidence of accidents in the Hamadan province during 2009 to 2014. Pajouhan Scientific Journal. 2016;14(2):8-16. (Persian)

2. Esmaeili Z, Vaezzadeh N. Injury patterns in children under 15 years of natural disasters in the province 1999 2000. Journal of Mazandaran University of Medical Sciences. 2001;10(29):1-7. (Persian)

3. Bakhshi H, Asadpoor M, Kazemi M, Etminan rad S. Distribution of injured patients admitted to the hospital emergency department-Hazrat Ali Ibn Abi Talib (AS), Rafsanjan. Payesh. 2007;5(2):113-121. (Persian)

4. Khosravi S, Ghafari M. An epidemiological study of domestic accidents in the population covered urban and rural health centers in Shahrekord, 1999. Journal of Shahrekord University of Medical Sciences. 2004;5(2):54-64. (Persian)

5. Sridharan L, Crandall M. Injury and health among children in vulnerable families. Journal of Trauma and Acute Care Surgery. 2011;70(6):1539-1545.

6. Amirzadeh F, Tabatabaiee S. Incidence rate and causes of accidents among the students of shiraz Guidance schools. Journal of Kerman University of Medical Sciences. 2007;14(1):55-60. (Persian) referred to home health, health centers and hospitals in Zanjan, 1999. Journal of Zanjan University of Medical Sciences And Health Services. 2001;8(33):41-46. (Persian)

8. Jadid milani M, Sohail Arshadi F, Asadi Noghabi A. Text book of Community Health Nursing 1,2,3. 14, editor. Tehran:Andisheh Rafih;2009. (Persian)

9. Helm Seresht P, Del Pishe E. Community Health Nursing. 3, editor. Tehran:Chehr;2004. (Persian)

10. Thein M, Lee B, Bun P. Childhood injuries in Singapore: A community nationwide study. Singapore Medical Journal. 2005;46(3):116-121.

11. Mazlomi S, Fallahzade H. Prevalence of events in individuals under 20 years of Yazd city. Payesh. 2003;1(4):21-25. (Persian)

12. Fathi Sheikhi M, Shamsi M, Khorsandi M, Ranjbaran M. The Measurement of Health Belief Model (HBM) constructs in the prevention of accidents and injuries in children in Khorramabad 2014. Arak Medical University Journal. 2015;18(94):69-77. (Persian)

13. Gholamaliee B, Khazaei S, Jamorpour S, Mohammadian Hafshejani A, Salehinia $H$. Epidemiological assessing of motorcyclists' countrylevel traffic accidents, 2013. Pajouhan Scientific 7. Mahram M, Derakhshandeh J, Jamshidifarsani M, Journal. 2015;14(1):12-21. (Persian) 


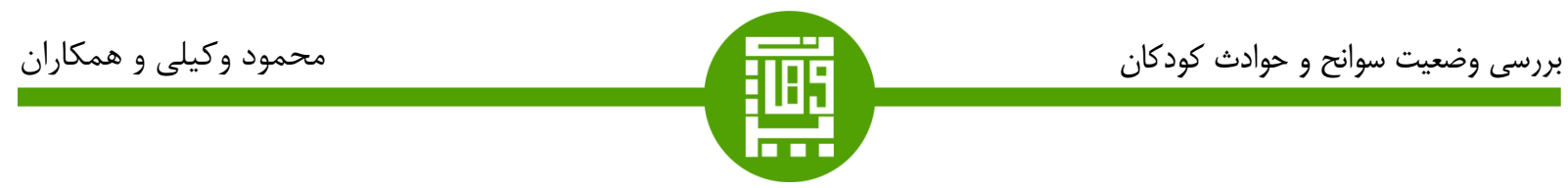

14. Mahfozi A, Kahani A, Masihi F, Abolmaasomi

F. Prevalence of mortality in children under 12 years of events referred to Tehran Legal Medicine in four (1996, 1997, 1998 and 1999). Forensic Medicine. 2007;7(24):5-14.

15. Ganveer G, Tiwari R. Injury pattern among nonfatal road traffic accident cases: A cross-sectional study in central India. Indian Journal of Medical Sciences. 2005;59(1):9-12.

16. Khodadadi H, Asadpoor M, Zohrehkermani S, Ravari A. Frequency of injuries in children under 15 years admitted to the emergency hospital of Imam Ali Ibn Abi Talib (AS) in Rafsanjan 1999-2000. Journal of Rafsanjan University of Medical Sciences. 2007;5(3):201-208. (Persian)

17. Bayat M, Shahsavari A, Forughi S, Mirzajani F,
Alamneshan F. Assessment of accidents' prevalence in children under 5 year referred to emergency ward. Journal of Mandish. 2012;2(2-3):26-32. (Persian)

18. Izadi Z. Epidemiology of documented accident in childeren under 15 years old in kerman-2014 [M.D. Thesis]. Kerman:Kerman of Medical Sciences;2015. (Persian)

19. Nekooee Moghadam M, Amiresmaelee M, Ghorbani R, Shikhani H, Navabi Z. Survey of under-5year-old children injury and accident mortality causes in the city of Kerman in 2013. Journal of Health-Based Research. 2015;1(1):1-12.

20. Sasan M, Beikzadeh A, Saeedinejat S, Deldar K, Khajedelooie M. Epidemiology of infants and toddlers 6-24 month. Medical Journal of Mashhad University of Medical Sciences. 2011;54(4):201-206. (Persian) 


\title{
Epidemiological study of accidents in children under 6 years of Azadshahr Yazd in 2011
}

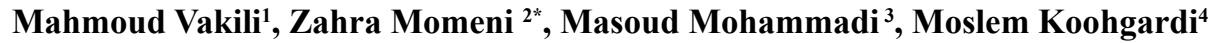 \\ 1. Associate Professor of Social Medicine, Faculty of Medicine, Shahid Sadoughi University of Medical Sciences, Yazd, Iran \\ 2. MSc of Epidemiology, Department of Biostatistics \& Epidemiology, Health Faculty, Shahid Sadoughi University of Medical \\ Sciences, Yazd, Iran \\ 3. MSc of Epidemiology, Department of Social Medicine, Faculty of Medicine, Kermanshah University of Medical Sciences, \\ Kermanshah, Iran \\ 4. BSc of Public Health, Health Center of Dayyer, Bushehr, Iran
}

\section{Irtiele Infor}

Recieved: 29 Feb. 2016

Accepted: 2 Jun. 2016

\section{Keपwords}

Accidents and Injuries

Epidemiology

Children under 6 years

Yazd

\section{Oorerponding Author}

Zahra Momeni, MSc of Epidemiology, Department of Biostatistics \& Epidemiology, Health Faculty, Shahid Sadoughi University of Medical Sciences, Yazd, Iran

Tel: +98936361089

Email: Zmomeni547@Gmail.com Oitation

Vakili M, Momeni Z, Mohammadi M, Koohgardi M. [Epidemiological study of accidents in children under 6 years of Azadshahr Yazd in 2011]. Pajouhan Scientific Journal. 2016;14(3):49-57

\section{A b stio a}

Introduction: Accidents are one of public health challenges and the most important causes of children mortality in the world and Iran. Considering the vulnerability of children, cognition of accident patterns can provide appropriate strategies to prevent accidents. The present study aimed to epidemiologically investigate accidents in children under six years of age.

Methods: This descriptive-analytical study was of cross-sectional studies. The information of 300 children under six years of age was collected by the Quota sampling from mothers reoffering to the health centers of Azadshahr in fall 2011 with a check list through interviews. The data were analyzed with the Chi-square test (SPSS version 21) after encoding.

Results: The mean age of the studied children and mothers were 5.30 and 26 years, respectively. The results showed that $78.4 \%$ of the children have had an accident. Physical injury (50.7\%), burn (15.3\%), fall (12\%), poisoning $(11 \%)$, traffic accident $(10.3 \%)$ and drowning $(0.7 \%)$ were the reasons for children accidents. The children of employed fathers and parents, who had higher education, had fewer accident and this difference was statistically significant $(\mathrm{P}<0.001)$.

Conclusion: The rate of accidents in Azadshahr is a higher figure in comparison with that of relevant studies. Therefore, it is suggested that preventive measures like parent training can be applied to reduce accident rates in children. 